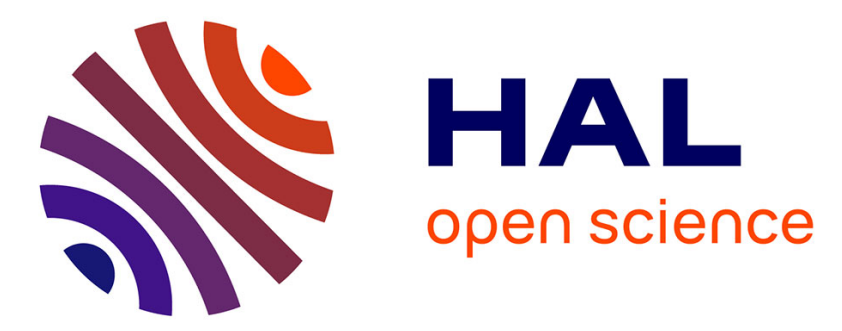

\title{
An investigation into the effects of silver nanoparticles on antibiotic resistance of naturally occurring bacteria in an estuarine sediment
}

Martin Mühling, Adam Bradford, James W. Readman, Paul J. Somerfield, Richard D. Handy

\section{To cite this version:}

Martin Mühling, Adam Bradford, James W. Readman, Paul J. Somerfield, Richard D. Handy. An investigation into the effects of silver nanoparticles on antibiotic resistance of naturally occurring bacteria in an estuarine sediment. Marine Environmental Research, 2009, 68 (5), pp.278. 10.1016/j.marenvres.2009.07.001 . hal-00520358

\section{HAL Id: hal-00520358 https://hal.science/hal-00520358}

Submitted on 23 Sep 2010

HAL is a multi-disciplinary open access archive for the deposit and dissemination of scientific research documents, whether they are published or not. The documents may come from teaching and research institutions in France or abroad, or from public or private research centers.
L'archive ouverte pluridisciplinaire HAL, est destinée au dépôt et à la diffusion de documents scientifiques de niveau recherche, publiés ou non, émanant des établissements d'enseignement et de recherche français ou étrangers, des laboratoires publics ou privés. 


\section{Accepted Manuscript}

An investigation into the effects of silver nanoparticles on antibiotic resistance of naturally occurring bacteria in an estuarine sediment

Martin Mühling, Adam Bradford, James W. Readman, Paul J. Somerfield, Richard D. Handy

PII:

S0141-1136(09)00093-2

DOI: 10.1016/j.marenvres.2009.07.001

Reference: MERE 3356

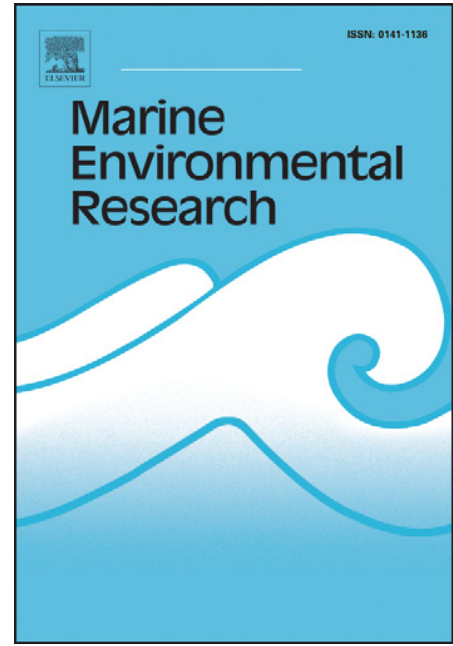

To appear in:

Marine Environmental Research

Received Date:

5 March 2009

Revised Date:

17 June 2009

Accepted Date:

3 July 2009

Please cite this article as: Mühling, M., Bradford, A., Readman, J.W., Somerfield, P.J., Handy, R.D., An investigation into the effects of silver nanoparticles on antibiotic resistance of naturally occurring bacteria in an estuarine sediment, Marine Environmental Research (2009), doi: 10.1016/j.marenvres.2009.07.001

This is a PDF file of an unedited manuscript that has been accepted for publication. As a service to our customers we are providing this early version of the manuscript. The manuscript will undergo copyediting, typesetting, and review of the resulting proof before it is published in its final form. Please note that during the production process errors may be discovered which could affect the content, and all legal disclaimers that apply to the journal pertain. 
1 An investigation into the effects of silver nanoparticles on antibiotic resistance of

2 naturally occurring bacteria in an estuarine sediment

3

4

5 Martin Mühling $^{1}{ }^{*}$, Adam Bradford ${ }^{1,2)}$, James W. Readman ${ }^{1)}$, Paul J. Somerfield ${ }^{1)}$ and

6 Richard D. Handy ${ }^{2)}$

7

$8 \quad{ }^{1)}$ Plymouth Marine Laboratory, Prospect Place, The Hoe, Plymouth PL1 3DH, UK

$9 \quad{ }^{2}$ Ecotoxicology and Stress Research Group, School of Biological Sciences, University of

10 Plymouth, Drake Circus, Plymouth PL4 8AA, UK

11

*Corresponding author: Dr Martin Mühling

13

Plymouth Marine Laboratory

14

15

16

Prospect Place

The Hoe

17

Plymouth PL1 3DH

England, UK

e-mail: mmuh@pml.ac.uk

19

Tel. +44-(0)1752-633416 (office)

Tel. +44-(0)1752-633100 (switchboard)

21

Fax. +44-(0)1752-633101

22

23 Running title:

24 Effects of silver nanoparticles on bacterial antibiotic resistance 
27 Key words:

28 bacteria, antibiotic resistance, metal resistance, nanoparticle, nanosilver, marine, pollution 29

30 


\section{ABSTRACT}

32 The aim of this study was to test whether silver nanoparticles (Ag-NPs) released into

33 estuarine environments result in increased antibiotic resistance amongst the natural bacterial

34 population in estuarine sediments. A 50-day microcosm exposure experiment was carried

35 out to investigate the effects of Ag-NPs (50 $\mathrm{nm}$ average diameter) on the antibiotic resistance

36 of bacteria in sediments from an estuary in southwest England. Experimental microcosms

37 were constructed using $3.5 \mathrm{~kg}$ sediment cores with 201 of overlaying seawater treated with

38 (final) Ag-NPs concentrations of 0, 50 or $2000 \mu \mathrm{g} \mathrm{l}^{-1}(\mathrm{n}=3)$. Sediment samples were

39 screened at the end of the exposure period for the presence of bacteria resistant to eight

40 different antibiotics. Multivariate statistical analyses showed that there was no increase in

41 antibiotic resistance amongst the bacterial population in the sediment due to the dosing of

42 the microcosms with Ag-NPs. This study indicates that, under the tested conditions, Ag-NPs

43 released into the coastal marine environment do not increase antibiotic resistance among

44 naturally occurring bacteria in estuarine sediments. These results contrast previous findings

45 where antimicrobial effects of Ag-NPs on key bacterial species in laboratory experiments

46 have been demonstrated, and reasons for this are discussed. The negligible effects

47 demonstrated on bacterial populations under the selected estuarine conditions, provide

48 important information on no observed effect concentrations (NOECs) for environmental

49 regulation. 


\section{INTRODUCTION}

Nanoparticles (NPs), which can broadly be defined as having one dimension between 1 and $100 \mathrm{~nm}$ (Masciangioli and Zhang, 2003), are increasingly used in consumer goods.

However, there are great uncertainties about the environmental fate and effects of anthropogenically produced NPs which stems from a lack of understanding the behaviour of these NPs (Colvin, 2003; Owen and Handy, 2007). One of the NPs that has been utilised increasingly during recent years in a wide range of products are silver NPs (Ag-NPs). This relates to the antimicrobial properties of Ag which, for example, has been used for a long time as a biocide in the treatment of burns (Klasen, 2000) and in wound dressings. The antimicrobial activity of $\mathrm{Ag}$ is thought to be due to the binding of the $\mathrm{Ag}^{+}$cation to electron donor groups in biological molecules containing sulphur, oxygen or nitrogen (e.g. enzymes) which, in turn, results in the loss of their function (Uchida et al. 2003; Kumar and Münstedt 2005). Another explanation is based on the generation of free radicals from the surface of the Ag-NPs which then lead to a breakdown of bacterial membrane function (Kim et al. 2007).

However, McHugh and colleagues reported as early as 1975 the emergence of a silver nitrate resistant strain of Salmonella typhimurium in a hospital burns unit which also proved to be resistant to several antibiotics (McHugh et al. 1975). Moreover, it is well documented that metal contaminated sites have increased numbers of antibiotic resistant bacteria (Wright $e t$ al. 2006, Baker-Austin et al. 2006). It is important to understand that, despite the absence of any antibiotic at these sites, the resistance to antibiotics is often not lost by the bacterial cell as the co-selection of heavy metal and antibiotic resistance is frequently due to plasmid encoded resistance genes for both metal and antibiotic resistance (e.g. Davis et al. 2005, Hernández et al. 1998). Therefore, it is not surprising that heavy metal contaminated soils have been found to harbour more plasmids than uncontaminated soils (Rasmussen and Sorensen 1998). Furthermore, the linkage of these genes on plasmids allows them to be 
transferred to other cells via horizontal gene transfer, thus facilitating the spreading of both resistance patterns despite the presence of only one selective pressure.

Nevertheless, Ag in form of Ag-NPs is being increasingly integrated into products widely available on the market, such as cosmetics, paints, food containers and clothing. One of the products of most environmental concern are washing machines used to impregnate clothes with Ag-NPs to avoid the growth of odour-producing bacteria as the Ag-NPs can leach out of fabrics (Benn and Westerhoff 2008). Consequently the most probable environmental exposure route of Ag-NPs is through wastewaters and surface waters (Boxall et al. 2007).

Based on this knowledge and the fact that in England and Wales it has been estimated that more than one-third (ca. 37.5\%) of the total sewage treatment plant effluents are discharged into estuarine and coastal environments (Environment Agency, 1999), it was decided to investigate the potential impact of Ag-NP pollution on the natural bacterial populations on the surface of estuarine sediment where Ag-NPs are likely to accumulate over time. A 30day microcosm study was designed in which Ag-NPs were added from a stock solution to estuarine sediment samples (in triplicate) for 20 days yielding a final cumulative treatment of either $0 \mu \mathrm{g}^{-1}$ (control), $25 \mu \mathrm{g} \mathrm{l^{-1 }}$ or $1000 \mu \mathrm{g} \mathrm{l^{-1 }}$ (Bradford et al., 2009). The experimental tanks were left for a further 10 days to allow for any recovery. Although the overall concentration of Ag-NPs in the water column increased steadily during the 20 days of dosing there was no influence on the abundance of heterotrophic prokaryotes in the estuary water. Similarily, despite the predicted accumulation of the Ag-NPs in the surface layer of the sediment ( top $3 \mathrm{~mm})$, there were only negligible differences in bacterial diversity between treatments, suggesting that under the selected experimental regime Ag-NPs present little or no impact on estuarine sediment bacterial diversity (Bradford et al., 2009). Although the chemical fate of the Ag-NPs after their release into the microcosms was not examined, it is believed that physicochemical parameters in the brackish environment (such as salinity and 
100

101

102

103

104

105

106

107

108

109

110

111

112

113 114 below.

115

116

117

118

119

120

121

122

123

organic matter content) might render Ag-NPs less toxic and unreactive within a short time frame of their release (see physico-chemistry in Handy et al., 2008). Nevertheless, it can be hypothesised that pollution of an estuarine environment with Ag-NPs can lead to an increase in the presence of silver-resistant bacteria in the sediment surface and, through co-selection, lead to an enrichment of antibiotic resistant bacteria in the natural population. Therefore, we investigated in the present study the potential impact of Ag-NPs on the occurrence of antibiotic resistance in natural bacterial assemblages using subsamples from the estuarine sediment surfaces from the experiment, but with a prolonged exposure time.

\section{MATERIALS AND METHODS}

Details on the collection of environmental samples, the experimental design of the microcosm exposure and sampling as well as the experimental and statistical analyses of the samples from the microcosms are described by Bradford et al. (2009). A summary of relevant information, as well as modifications to the methods used previously, are outlined

\section{Experimental Design}

Glass microcosms were prepared in triplicate for each exposure concentration, and were maintained covered and continuously aerated in a constant-temperature culture room at $15^{\circ} \mathrm{C}$. The following three exposure treatments were carried out: $0 \mu \mathrm{g}^{-1}$ of Ag-NPs in the overlaying estuary water (control tanks T01, T02, T03); $50 \mu \mathrm{g} 1^{-1}$ Ag-NPs (T04, T05, T06); and $2000 \mu \mathrm{g} \mathrm{l}^{-1} \mathrm{Ag-NPs}$ (T07, T08, T09) to represent a low-level contamination $\left(50 \mu \mathrm{g} \mathrm{l}^{-1}\right)$, while the $2000 \mu \mathrm{g} \mathrm{l}^{-1}$ concentration was selected as it is much higher than predicted future environmental concentrations resulting from anthropogenic pollution (Boxall et al., 2007). 
124 The microcosm tanks consisted of sediment (ca. L $28 \times$ W 17 x D $7 \mathrm{~cm}$ ) with 201 of

125 overlaying estuarine seawater. Each microcosm and all of the equipment used for sampling

126 or aeration was thoroughly acid washed ( $0.5 \%$ nitric acid, over night) to remove trace

127 metals from the surface of the glassware. In order to minimise the loss of any added Ag-NP

128 material by adsorption onto the tanks, the microcosms, except those used as controls, were

129 saturated with Ag-NPs, by pre-soaking them with an Ag-NP solution (1/40 ${ }^{\text {th }}$ of the final

130 concentration of Ag-NPs used - see below) for $1 \mathrm{~h}$. The estuarine sediment samples were

131 collected from an intertidal area at the mouth of the Tamar Estuary (St John's lake mud flats,

132 OSGB grid ref. SX412539). Care was taken to ensure that there was minimal disturbance of

133 the surface layer and stratification of the sediment, and that any large invertebrates were

134 avoided during collection. Upon returning to the laboratory the sediment samples were

135 placed into the individual microcosm tanks and samples were allocated randomly to

136 treatments to minimise any sampling bias.

137 The sediment samples were exposed to a cumulative dose of Ag-NPs that totalled 0

138 (control), 50 and $2000 \mu \mathrm{g} \mathrm{l}^{-1}$ of overlaying intertidal seawater. The dosing was carried out in

139 two steps. $1 / 40^{\text {th }}$ of the final concentration of Ag-NPs was added daily to the overlaying

140 seawater over a period of 20 days; i.e. $0.25 \mathrm{ml}$ and $10 \mathrm{ml}$ of a $100 \mu \mathrm{g} \mathrm{ml}^{-1}$ stock solution

141 were added to the 50 and $2000 \mu \mathrm{g} \mathrm{l}^{-1}$ tanks, respectively. The microcosms were then left

142 untreated for 10 days, followed by renewed daily dosing $\left(1 / 40^{\text {th }}\right.$ of the final concentration)

143 for another 20 days (i.e. a total exposure time of 50 days).

\section{Characterisation of Ag-NPs}

146 The Ag-NP test material (Sigma Aldrich Silver nano; $<100 \mathrm{~nm}$ ) was selected as the Ag-NPs

147 were representative in size to those used by Yoon et al. (2007) and Pal et al. (2007). TEM 
148 revealed that the sonicated Ag-NPs stock solution $\left(100 \mathrm{mg} \mathrm{l}^{-1}\right)$ used for the dosing was well

149 dispersed and that the individual particles (if assumed to be spheroidal) had an average

150 diameter of $58.6 \mathrm{~nm}$ (standard deviation $=18.6 \mathrm{~nm} ; \mathrm{n}=64)$.

152 Analysis of water samples and metals in sediments

153 Water samples $(10 \mathrm{ml})$ were collected for metal analysis before and after each daily addition

154 of Ag-NPs, and samples were also collected for general nutrient analyses of the seawater (50

$155 \mathrm{ml}$ samples from each tank). Nutrient analyses were performed according to Woodward

156 (2001) using a Technicon segmented flow colorimetric autoanalyser. The following water

157 quality parameters were measured at 8 time points (days $0,1,4,10,15,20,25,30$ ) during

158 the first 30 days of the incubation: salinity (mean \pm S.E.M: $29.47 \pm 0.15 \%$ ), dissolved

159 oxygen $(100.7 \pm 0.97 \%), \mathrm{pH}(7.82 \pm 0.12)$, ammonium $(23.9 \pm 1.9 \mu \mathrm{M})$, nitrate $(58 \pm 2.1$

$160 \mu \mathrm{M})$, nitrite $(9.7 \pm 1.1 \mu \mathrm{M})$, phosphate $(4.7 \pm 0.1 \mu \mathrm{M})$, silicate $(28.5 \pm 1.3 \mu \mathrm{M})$, temperature

$161 \quad\left(13.17 \pm 0.06^{\circ} \mathrm{C}\right)$.

162 Metal analysis was performed on water and sediment samples by inductively coupled

163 plasma-optical emission mass spectrometry (ICP-OES, Varian 725-ES) using matrix

164 matched standards and $1 \%$ yttrium $\left(\mathrm{Y}^{39}\right)$ oxide as an internal standard in samples (see

165 Bradford et al., 2009, for further details). A certified estuarine reference material (LGC

166 6137, Laboratory of the Government Chemist) was treated likewise as an internal control.

167 Measured trace element concentrations in the sediments at the start (i.e. day 0 ) of the

168 exposure experiment were very similar: ( $m g$ metal $\mathrm{kg}^{-1}$ dry weight, mean \pm S. E. M., $\mathrm{n}=$

169 144); Ca, $8477 \pm 459 ; \mathrm{Cu}, 160 \pm 7 ; \mathrm{Fe}, 36994 \pm 1682 ; \mathrm{K}, 2801 \pm 152 ; \mathrm{Mg}, 9402 \pm 490 ; \mathrm{Na}$

$17030642 \pm 2332 ; \mathrm{Zn} 235 \pm 11$.

171 ICP-OES of seawater samples from the microcosms treated with $2000 \mu \mathrm{g}^{-1} \mathrm{Ag}$-NPs

172 revealed that Ag accumulated in the overlaying seawater during the first period of daily 
173 dosing (i.e. first 20 days) to approximately $50 \mu \mathrm{g}^{-1}$ and decreased then to less than $10 \mu \mathrm{g} \mathrm{l}^{-1}$

174 at day 30, after which another 20 days of dosing was carried out (no analyses were carried

175 out for this time period). Parallel analyses of extracts of samples from the surface of the

176 sediment collected during the first 30 days of the exposure time revealed that the $\mathrm{Ag}$

177 accumulated in the surface layer of the sediment. Whilst Ag could be detected and quantified

178 in all of the seawater and sediment samples from the $2000 \mu \mathrm{g}{ }^{-1}$ dosed microcosms

179 (following the initial dosing), in the $50 \mu \mathrm{g} \mathrm{l}^{-1}$ treated microcosms, $\mathrm{Ag}$ was below the

180 detection limit (approx. $1 \mathrm{ng} \mathrm{l}^{-1}$ ) of the method used in any of the overlaying seawater

181 samples and was detected only in the sediment sample collected on day 25, providing further

182 evidence that the Ag-NPs accumulate at the surface of the sediment. Ag was not detectable

183 in either the overlaying seawater or the sediment from any of the control microcosms.

184

185 Screening for antibiotic resistant bacteria

186 A 5-ml syringe (without the plunger and with the tip removed) was used to remove a core

187 sample of the sediment on day 50 of the incubation from each of the nine microcosms. A

188 100-mg aliquot of the surface layer of each of these samples from the sediment cores was

189 collected and transferred into $10 \mathrm{ml}$ of filtered $(0.2 \mu \mathrm{m})$ seawater and mixed by vortexing. 50

$190 \mu \mathrm{l}$ of this suspension and of two 10-fold dilutions of it were transferred onto a 10-times

191 diluted version of marine broth (per litre of estuarine (29\%o salinity) seawater: $0.5 \mathrm{~g}$

192 peptone, $0.1 \mathrm{~g}$ yeast extract, $0.01 \mathrm{~g} \mathrm{FePO}_{4}-\mathrm{H}_{2} \mathrm{O}$ was added and was then solidified using

$1931.5 \%(w / v)$ agar). Each of the medium plates contained one of 8 different antibiotics (as well

194 as cycloheximide (20 $\mathrm{g} \mathrm{ml}^{-1}$; Melford Laboratories Ltd., Chelsworth, UK) to inhibit fungal

195 growth). The concentration of the antibiotics was based on those suggested by the DIN -

196 Deutsches Institut für Normung e.V. (1998). Antibiotics (Sigma-Aldrich, Poole, UK) used

197 were erythromycin $\left(20 \mu \mathrm{g} \mathrm{ml}^{-1}\right)$, oxytetracycline $\left(20 \mu \mathrm{g} \mathrm{ml}^{-1}\right)$, sulfadiazine $\left(32 \mu \mathrm{g} \mathrm{ml}^{-1}\right)$, 
198 trimethoprim $\left(32 \mu \mathrm{g} \mathrm{ml}^{-1}\right)$, lincomycin $\left(32 \mu \mathrm{g} \mathrm{ml}^{-1}\right)$, ceftazidime $\left(32 \mu \mathrm{g} \mathrm{ml}^{-1}\right)$, amoxicillin $(20$

$\left.199 \mu \mathrm{g} \mathrm{ml}^{-1}\right)$ and vancomycin $\left(32 \mu \mathrm{g} \mathrm{ml}^{-1}\right)$. Additionally, to evaluate the efficacy of the antibiotic

200 treatments, aliquots were also transferred onto marine broth plates containing only the

201 fungicide cycloheximide $\left(20 \mu \mathrm{g} \mathrm{ml}^{-1}\right)$. Plates were incubated at $15^{\circ} \mathrm{C}$ for seven days.

202

203 Statistical analyses

204 The interactive effects of different antibiotic treatments and the presence or absence of $\mathrm{Ag}$

205 were analysed using counts (colony forming units - cfus) from antibiotic-containing plates at

206 the end of the seven-day incubation. A Euclidean distance matrix of differences between

207 every pair of samples was calculated and used to conduct tests of differences between groups

208 of samples, using permutation-based 2-way crossed Analysis of Variance (Anderson 2001;

209 McArdle and Anderson 2001). This procedure is formally equivalent to a standard ANOVA

210 but the flexibility and robustness of the permutation approach ameliorates the necessity for

211 variables to fulfil standard assumptions, such as normality. The analyses were implemented

212 in PRIMER 6 \& PERMANOVA+ 1 software (www.primer-e.com).

214 RESULTS

216 Environmental parameters of the microcosms

217 Analyses of biotic and abiotic parameters of the overlaying water samples were undertaken

218 at 8 time points (days $0,1,4,10,15,20,25,30$ ) during the first 30 days of the incubation.

219 There were no significant differences in water quality between the tanks (ANOVA, P > 0.05)

220 and the results from the measurement of dissolved oxygen, $\mathrm{pH}$ temperature and salinity were

221 in the normal range for this estuarine site. Similarly, there were no significant differences 
222 between microcosms in terms of bacterial numbers in the overlaying water $(P=0.725)$,

223 though their numbers fluctuated over the time course of the incubation.

224

225

226

228

229

230

231

232

234

235

236

238

\section{Antibiotic resistance in the estuarine sediment samples}

The 10-fold dilutions of the sediment sample suspensions were found to provide the most reliable numbers for subsequent statistical analyses. Undiluted suspensions produced $>700$ colonies per plate, which were graded the same (i.e. 700 cfus) thereby underestimating within-treatment variability. The 100 -fold diluted samples often produced too few cfus to be counted. The cfu counts from the undiluted and the 10-fold dilution of the sediment samples are listed in Table 1. Data from the test on erythromycin-resistant bacteria were excluded from the analysis as no bacteria grew on the plate. Permutation-based ANOVA (Table 2) showed that there is no interaction between the effects of antibiotics and $\mathrm{Ag}$. The $\mathrm{Ag}$ treatments, therefore, had no significant effect on bacterial counts. Different antibiotic treatments, however, did have significantly different effects on the counts. These were examined in more detail (Table 3). As expected, all counts from samples treated with all antibiotics differed significantly from those in samples treated solely with the antifungal agent cycloheximide. No colonies grew in the erythromycin treatment. Samples treated with other antibiotics effectively fell into two groups. Counts were significantly lower in samples treated with oxytetracycline or amoxycillin than they were in samples treated with sulfadiazine, trimethoprim, lincomycin or vancomycin, although the effects of the latter were variable. Samples treated with ceftazidime tended to have intermediate counts that overlapped the two groups (Table 1).

\section{DISCUSSION}




\section{Antibiotic resistance in estuarine microcosms and the impact of Ag-NPs}

248 The presented results reiterate the now commonly accepted concept that environmental 249 populations of bacteria include a wide range of antibiotic resistant strains. Although it is well 250 known that some of this antibiotic resistance is intrinsic and natural to bacteria (D'Costa et 251 al. 2006), it has also been demonstrated that it is caused, to a large extent, through the 252 release of antibiotics from agricultural or human prescriptions into the environment (e.g. 253 Aarestrup et al. 2000; Goni-Urriza et al., 2000).

254 Another factor that has been found to result in increased antibiotic resistance is pollution 255 with heavy metals in soils (Berg et al. 2005) or in sediments, biofilms and the water column 256 of polluted rivers (Stepanauskas et al. 2005; Wright et al. 2006). This correlation has also 257 been demonstrated in heavy metal (cadmium, nickel) spiked freshwater microcosm 258 experiments which showed an increase of antibiotic resistant bacteria with increasing heavy 259 metal concentrations (Stepanauskas et al. 2006). Given the increasingly wide-spread use of 260 Ag-NPs in consumer and medical products it is of great importance to evaluate the potential 261 link between environmental pollution by Ag-NPs and antibiotic resistance.

262 The present experiment, however, did not find such a correlation with any of the antibiotics 263 tested, which were selected based on their high prescription rate among human patients 264 (amoxicillin), their importance as an "antibiotic of last resort" (vancomycin), their high 265 usage in farming (oxytetracycline), and on the fact that bacteria resistant to $\beta$-lactam based

266 antibiotics are increasingly found in clinical and environmental environments (ceftazidime).

267 Other antibiotics were recommended for investigation by Dr Alistair Boxall (University of 268 York, personal communication; see also Boxall et al., 2006) due to their persistence in the 269 environment (e.g. lincomycin) or their previous detection in other estuaries (e.g. 
270

271

272

273

274

275

276

277

278

279

280

281

282

283

284

285

286

287

288

289

290

291

292

293

294

erythromycin). The fact that the bacterial counts for amoxicillin were at the lower end of all of the antibiotics is likely to be due to its fast degradation both inside the human body and upon release into the environment (Boxall, personal communication). Similarly, in field experiments the concentration of free oxytetracycline was also found to decrease within the first few days after spiking into agricultural soils (Boxall et al., 2006) or into manure samples (Loke et al. 2003). In contrast to these, trimethoprim and lincomycin are well known to be less degradable in the environment (Ingerslev and Halling-Sørensen 2000, Boxall et al., 2006). This correlates with the high abundance of the antibiotic resistant bacteria found in this study. However, the history of any antibiotic contamination at the sampling site prior to this study is unknown. The relatively high number of bacterial counts of vancomycin-resistant bacteria is of particular concern, as this antibiotic is one of very few that are still active against some strains of methicillin-resistant Staphylococcus aureus (e.g. Maclayton and Hall II 2007). Investigations into bacterial diversity in the sediment surface throughout the experimental exposure period did not reveal any significant changes (Bradford et al., 2009).

It is unlikely that the exposure time (50 days) to the Ag-NPs was too short to generate antibiotic resistant bacteria, as bacteria undergo multiple replications each day and antibiotic resistance can be located on plasmids. This is further confirmed by the fact that Stepanauskas et al. (2006) found an increase in antibiotic resistant bacteria after a 7-day incubation to $1 \mathrm{mM}$ concentrations of $\mathrm{CdCl}_{2}$ and $\mathrm{NiCl}_{2}$. Additionally, the time period of the exposure is also thought to be sufficient for bacteria to acquire the relevant resistance genes through horizontal gene transfer as the genes responsible for resistance to heavy metals, such as the silE gene which has been shown to confer resistance to Ag (e.g. Davis et al. 2005), are encoded on plasmids or other highly transferable gene cassettes and integrons which 
represent mobile genetic elements that facilitate horizontal gene transfer (Fluit and Schmitz 2004).

There are, however, a number of potential explanations for the results presented which, taken together, suggest that the impact of Ag-NPs on natural bacterial populations is unpredictable and probably needs to be investigated for each environment individually. We believe that the main reason for this unpredictability lies in the specific abiotic parameters of a particular environment. Estuaries, in particular, differ from other environments in that the mixing of river water and seawater generates complex gradients which control the formation of colloids and their removal through flocculation (e.g. Sholkovitz 1978, Stolpe and Hassellöv 2007).

Ward and Kramer (2002) showed that the ratio of the $\mathrm{Ag}$ species $\mathrm{Ag}^{+}, \mathrm{AgCl}^{\circ}, \mathrm{AgCl}_{2}^{-}$, $\mathrm{AgCl}_{3}{ }^{2-}$ depend strongly on the salinity of the water, with higher salinity favouring the latter two complexes. The relative abundance of the $\mathrm{Ag}^{+}(1.7 \%)$ and $\mathrm{AgCl}^{\circ}(42 \%)$ species is considerably higher at a salinity of $1 \%$ (Ward and Kramer, 2002) as compared to a salinity of $25 \%$ where their concentration will be reduced to approximately $1.4 \%\left(\mathrm{Ag}^{+}: 0.004 \%\right.$; $\left.\mathrm{AgCl}^{\circ} 1.4 \%\right)$ with the $\mathrm{Ag}$ complexes comprising the remaining $98 \%\left(\mathrm{AgCl}_{2}^{-}: 49 \% ; \mathrm{AgCl}_{3}{ }^{2-}\right.$ : $49 \%$ ). If $\mathrm{AgCl}_{2}{ }^{-}$and $\mathrm{AgCl}_{3}{ }^{2-}$ prove indeed to lack antimicrobial activity then Ag-NPs would not exert selective pressure on natural bacterial population in marine environments and, therefore, would not result in co-selection of antibiotic resistance. Moreover, the charged nature of these colloids may also favour attachment to DOM and POM and thus further reduce their bioavailability. In contrast, the free $\mathrm{Ag}^{+}$cation and $\mathrm{AgCl}$ appear to be highly bioavailable (Engel et al. 1981, reviewed by Luoma et al. 1995) and possess antimicrobial activity (Uchida et al. 2003; Kumar and Münstedt 2005). Thus toxicity in estuarine environments could be more than 2 orders of magnitude lower than in non-saline water. However, this does not necessarily mean that in freshwater environments 
320

321

322

326

327

complexation with organics and, in particular, the formation of silver sulfide clusters (Rozan et al., 2000) can reduce toxicity to Daphnia magna (Bowles et al., 2002; Biachini et al., 2002). Such complexation could also lead to reduced antimicrobial activity (due to loss of bioavailability), and potentially to a reduction in antibiotic resistant bacteria.

Lok et al. (2007) have observed the loss of antibacterial activity of Ag-NPs against E. coli in high salinity media. They attributed this to aggregation of the NPs which could be overcome by premixing the Ag-NPs with bovine serum albumin (BSA). In the present study it was preferred to maintain unmodified environmental conditions as the dispersant is unlikely to occur in relevant concentrations in the environment; therefore, we used sonication of the stock solution prior to dosing of the microcosms.

In conclusion, the microcosm experiments undertaken in this study demonstrate that Ag-NPs do not result in an increase in antibiotic resistance of naturally occurring bacteria in estuarine sediments. This is in contrast to previous findings from heavy metal polluted natural environments or from heavy metal amended microcosm experiments, which showed that heavy metal contamination results in increased occurrence of antibiotic resistant bacteria.

The study, therefore, indicates that a crucial step in the effects of Ag-NPs, and possibly other NPs, is connected to the bioavailability of the particles. A clearer understanding of this aspect, particularly of the chemical behaviour of the NPs once released into the environment and the abiotic factors that may deactivate the antimicrobial effect of the particles, is required to better understand their behaviour, to validate their NOECs and to be able to predict the potential consequences of environmental pollution from the emerging applications of Ag-NPs and nanoparticles in general. Until then it will not be possible to extrapolate the results from laboratory experiments carried out on bacterial isolates to the natural environment. 


\section{ACKNOWLEDGEMENTS}

347 This project was funded by a grant (NE/F01192X/1) from the Natural Environment Research 348 Council (NERC) of the UK as part of its Environmental Nanoscience Initiative (ENI). The

349 authors thank Andrew Atfield (University of Plymouth) for the preparation of the 350 nanoparticles.

\section{REFERENCES}

352 Aarestrup, F. M., Kruse, H., Tast, E., Hammerum, A. M., 2000. Jensen, L. B., Associations

353 between the use of antimicrobial agents for growth promotion and the occurrence of 354 resistance among Enterococcus faecium from broilers and pigs in Denmark, Finland, and 355 Norway. Microbial Drug Resistance 6, 63-70.

356 Anderson, M.J., 2001. A new method for non-parametric multivariate analysis of variance. 357 Austral Ecology 26, 32-46.

358 Baker-Austin, C., Wright, M.S., Stepanauskas, R., McArthur, J.V., 2006. Co-selection of 359 antibiotic and metal resistance. Trends in Microbiology 14, 176-182.

360 Benn, T.M., Westerhoff, P., 2008. Nanoparticle silver released into water from commercially 361 available sock fabrics. Environmental Science and Technology 42, 4133-4139.

362 Berg, J., Tom-Petersen, A., Nybroe, O., 2005. Copper amendment of agricultural soil selects 363 for bacterial antibiotic resistance in the field. Letters in Applied Microbiology 40, 146$364 \quad 151$.

365 Bianchini, A., Bowles, K.C., Brauner, C.J., Gorsuch, J.W., Kramer, J.R., Wood, C.M., 2000. 366 Evaluation of the effect of reactive sulfide on the acute toxicity of silver (I) to Daphnia 367 magna. Part 2: toxicity results. Environmental Toxicology and Chemistry 21, 1294-1300. 368 Bowles, K.C., Bianchini, A., Brauner, C.J., Kramer, J.R., Wood, C.M., 2000. Evaluation of 369 the effect of reactive sulfide on the acute toxicity of silver (I) to Daphnia magna. Part 1: 
description of the chemical system. Environmental Toxicology and Chemistry 21, 12861293.

372 Boxall, A.B.A., Tiede, K., Chaudhry, Q., 2007. Engineered nanomaterials in soils and water: 373 how do they behave and could they pose a risk to human health? Nanomedicine 2, 919374927.

375 Boxall, A.B.A., Fogg, L.A., Baird, D.J., Lewis, C., Telfer, T.C., Kolpin, D., Gravell, A., 376 Pemberton, E., Boucard, T., 2006. Targeted monitoring study for veterinary medicines in 377 the environment, Science Report: SC030183/SR, Bristol: Environment Agency, 120 pp.

378 Boxall, A. B. A., Chaudhry, Q., Sinclair, C., Jones, A., Aitken, R., Jefferson, B., Watts, W., 379 2007. Current and Future Predicted Environmental Exposure to Engineered 380 Nanoparticles; Central Science Laboratory: York; http://randd.defra.gov.uk/Document. $381 \quad$ aspx? DocumentID)2291.

382 Bradford, A., Handy, R., Readman, J., Atfield, A., Mühling, M., 2009. Impact of silver 383 nanoparticle contamination on the genetic diversity of natural bacterial assemblages in 384 brackish sediments. Environmental Science \& Technology

385 (http://pubs.acs.org/doi/abs/10.1021/es9001949).

386 Colvin, V.L., 2003. The potential environmental impact of engineered nanomaterials. Nature 387 Biotechnology 21, 1166-1170.

388 Davis, I.J., Richards, H., Mullany, P., 2005. Isolation of silver- and antibiotic-resistant

389 Enterobacter cloacae from teeth. Oral Microbiology and Immunology 20, 191-194.

390 D’Costa, V.M., McGrann, K.M., Hughes, D.W., Wright, G.D., 2006. Sampling the antibiotic $391 \quad$ resistome. Science 311, 374-377.

392 DIN - Deutsches Institut für Normung e.V. (1998) Methoden zur Empfindlichkeitsprüfung 393 von mikrobiellen Krankheitserregern gegen Chemotherapeutika, DIN 58940. Vol. 3, 394 Beuth Verlag, Berlin. 
Engel, D.W., Sunda, W.G., Fowler, B.A., 1981. Factors affecting trace metal uptake and toxicity to estuarine organisms. I Environmental parameters, in: Vernberg, J.F., Callabrese, A., Thurberg F.P. and Vernberg, W.B. (Eds.), Biological Monitoring of Marine Pollutants. Academic Press, New York, pp. 127-144.

Fluit, A.C. and Schmitz, F.-J. (2004) Resistance integrons and super-integrons. European Journal of Clinical Microbiology and Infectious Diseases 10, 272-288.

Goni-Urriza, M., Capdepuy, M., Arpin, C., Raymond, N., Caumette, P., Quentin, C., 2000. Impact of an urban effluent on antibiotic resistance of riverine Enterobacteraceae and Aeromonas spp. Applied and Environmental Microbiology 66, 125-132.

Handy, R.D., Kammer, F.v.d., Lead, J.R., Hassellöv, M., Owen, R., Crane, M. 2008. The ecotoxicology and chemistry of manufactured nanoparticles. Ecotoxicology 17, 287-314.

Hernández, A., Mellado, R.P., Martínez, J.L., 1998. Metal accumulation and vanadiuminduced multidrug resistance by environmental isolates of Escherichia hermannii and Enterobacter cloacae. Applied and Environmental Microbiology 64, 4317-4320.

Ingerslev, F., Halling-Sørensen, B., 2000. Biodegradability properties of sulfonamides in activated sludge. Environmental Toxicology and Chemistry 19, 2467-2473

Kalman, J., Turner, A., 2007. An evaluation of metal bioaccessibility in estuarine sediments using the commercially available protein, bovine serum albumin. Marine Chemistry 107, 486-497.

Kim, J.S., Kuk, E., Yu, K.N., Kim, J.-H., Park, S.J., Lee, H.J., Kim, S.H., Park, Y.K., Park, Y.H., Hwang, C.Y., Kim, Y.K., Lee, Y.S., Jeong, D.H., Cho, M.H., 2007. Antimicrobial effects of silver nanoparticles. Nanomedicine 3, 95-101.

Klasen, H.J., 2000. A historical review of the use of silver in the treatment of burns. II. Renewed interest for silver. Burns 26, 131-138. 
Kumar, R., Münstedt, H., 2005. Silver ion release from antimicrobial polyamide/silver composites. Biomaterials 26, 2081-2088.

Lok, C.N., Ho, C.-M., Chen, R., He, Q.-Y., Yu, W.-Y., Sun, H., Tam, P.K.-H., Chiu, J.F., Che, C.-M., 2007. Silver nanoparticles: partial oxidation and antibacterial activities. Journal of Biological Inorganic Chemistry 12, 527-534.

Loke, M.-L., Jespersen, S., Vreeken, R., Halling-Sørensen, B., Tjørnelund, J., 2003.

$$
\text { Determination of oxytetracycline and its degradation products by high-performance liquid }
$$
chromatography-tandem mass spectrometry in manure-containing anaerobic test systems. Journal of Chromatography B 783, 11-23.

Luoma, N.S., Ho, Y.B., Bryan, G.W., 1995. Fate, bioavailability and toxicity of silver in estuarine environments. Marine Pollution Bulletin 31, 44-54.

Maclayton, D.O., Hall II, R.G., 2007. Pharmacologic treatment options for nosocomial pneumonia involving methicillin-resistant Staphylococcus aureus. The Annals of Pharmacotherapy 41, 235-244.

Masciangioli, T., Zhang, W.X., 2003. Environmental technologies at the nanoscale.

$$
\text { Environmental Science and Technology 37, 102A-108A. }
$$

McArdle, B.H., Anderson, M.J., 2001. Fitting multivariate models to community data: a comment on distance-based redundancy analysis. Ecology 82, 290-297.

McHugh, G.L., Moellering, R.C., Hopkins, C.C., Swartz, M.N., 1975. Salmonella typhimurium resistant to silver nitrate, chloramphenicol, and ampicillin. Lancet 1, 235240.

Owen, R., Handy, R., 2007. Formulating the problems for environmental risk assessment of nanomaterials. Environmental Science and Technology 15, 5582-5588. 
442 Pal, S., Tak, Y.K., Song, J.M., 2007. Does the antibacterial activity of silver nanoparticles

443 depend on the shape of the nanoparticle? A study of the gram-negative bacterium

$444 \quad$ Escherichia coli. Applied Environmental Microbiology 73, 1712-1720.

445 Rasmussen, L.D., Sorensen, S.J., 1998. The effect of longterm exposure to mercury on the

446 bacterial community in marine sediment. Current Microbiology 36, 291-297.

447 Rozan, T.F., Lassman, M.E., Ridge, D.P., Luther, G.W. III, (2000) Evidence for

448 multinuclear $\mathrm{Fe}, \mathrm{Cu}$ and $\mathrm{Zn}$ molecular sulfide clusters in oxic river waters. Nature 406,

$449 \quad 879-882$.

450 Sholkovitz, E.R., 1978. The flocculation of dissolved Fe, Mn, Al, Cu, Ni, Co and Cd during

$451 \quad$ estuarine mixing. Earth and Planetary Science Letters 41, 77-86.

452 Sondi, I., Salopek-Sondi, B., 2004. Silver nanoparticles as antimicrobial agent: a case study

453 on E. coli as a model for Gram-negative bacteria. Journal of Colloid and Interface Science

$454 \quad 275,177-182$.

455 Stolpe, B., Hassellöv, M., 2007. Changes in size distribution of fresh water nanoscale

456 colloidal matter and associated elements on mixing with seawater. Geochimica

457 Cosmochimica Acta 71, 3292-3301.

458 Stepanauskas, R., Glenn, T.C., Jagoe, C.H., Tuckfield, R.C., Lindell, A.H., McArthur, J.V.,

459 2005. Elevated bacterioplankton tolerance to metals and antibiotics in metal-contaminated

$460 \quad$ industrial environments. Environmental Science and Technology 39, 3671-3678.

461 Stepanauskas, R., Glenn, T.C., Jagoe, C.H., Tuckfield, R.C., Lindell, A.H., King, C.J.,

462 McArthur, J.V., 2006. Coselection for microbial resistance to metals and antibiotics in

463 freshwater microcosms. Environmental Microbiology 8, 1510-1514.

464 Uchida, M., Yamamoto, T., Taniguchi, A., 2003. Reaction of silver ions and some amino

465 acids. Journal of Antibacterial and Antintifungal Agents 31, 695-704. 
466 Ward, T.J., Kramer, J.R., 2002. Silver speciation during chronic toxicity tests with the 467 mysid, Americamysis bahia. Comparitive Biochemistry and Physiology C 133, 75-86.

468 Woodward, E.M.S., Rees, A.P., 2001. Nutrient distributions in an anticyclonic eddy in the 469 northeast Atlantic Ocean, with reference to nanomolar ammonium concentrations. Deep$470 \quad$ Sea Research Part II 48, 775-793.

471 Wright, M.S., Peltier, G.L., Stepanauskas, R., McArthur, J.V., 2006. Bacterial tolerances to 472 metals and antibiotics in metal-contaminated and reference streams. FEMS Microbiology $473 \quad$ Ecology 58, 293-302.

474 Yoon, K.Y., Byeon, J.H., Park, J.H., Hwang, J., 2007. Susceptibility constants of 475 Escherichia coli and Bacillus subtilis to silver and copper nanoparticles. Science of the 476 Total Environment 373, 572-575. 
477 Table 1. Bacterial counts in form of colony forming units (cfus) on medium containing 478 cycloheximide and eight different antibiotics. The experiments were carried out in triplicate 479 (control/ $/ \mathrm{g} \mathrm{I}^{-1}$ overlying estuary water: microcosms $1,2,3 ; 25 \mu \mathrm{g}^{-1}$ : microcosms 4, 5, 6; $4801 \mathrm{mg} \mathrm{l}^{-1}$ : microcosms 7, 8, 9).

\begin{tabular}{lccccccccc}
\multicolumn{1}{c}{$\begin{array}{l}\text { Microcosm } \rightarrow \\
\text { Antibiotic }\end{array}$} & $\mathbf{1}$ & $\mathbf{2}$ & $\mathbf{3}$ & $\mathbf{4}$ & $\mathbf{5}$ & $\mathbf{6}$ & $\mathbf{7}$ & $\mathbf{8}$ & $\mathbf{9}$ \\
Cycloheximide & 108 & 65 & 100 & 130 & 142 & 100 & 105 & 97 & 250 \\
Erythromycin $^{2)}$ & 0 & 0 & 0 & 0 & 0 & 0 & 0 & 0 & 0 \\
Oxytetracycline $^{2)}$ & 6 & 9 & 3 & 5 & 5 & 5 & 4 & 0 & 9 \\
Amoxycillin $^{2)}$ & 1 & 15 & 2 & 9 & 5 & 13 & 0 & 0 & 3 \\
Ceftazidime $^{3)}$ & 6 & 15 & 11 & 8 & 6 & 5 & 8 & 4 & 17 \\
Sulfadiazine $^{3)}$ & 24 & 44 & 17 & 34 & 17 & 17 & 23 & 11 & 27 \\
Trimethoprim $^{3)}$ & 38 & 24 & 46 & 94 & 48 & 17 & 22 & 28 & 27 \\
Lincomycin $^{2)}$ & 28 & 51 & 23 & 76 & 27 & 37 & 25 & 14 & 23 \\
Vancomycin $^{3)}$ & 34 & 42 & 10 & 49 & 185 & 17 & 17 & 5 & 8
\end{tabular}

$481{ }^{1)}$ cycloheximide $\left(20 \mu \mathrm{g} \mathrm{mL}^{-1}\right)$ was added to any of the eight antibiotic-containing media to prevent fungal 482 growth; additionally, to evaluate whether the samples contained comparable numbers of bacteria, aliquots of 483 the samples were also transferred on solidified medium containing only cycloheximide $\left(20 \mu \mathrm{gL}^{-1}\right)$

$484{ }^{2)}$ used in a concentration of $20 \mu \mathrm{g} \mathrm{mL}^{-1} ;{ }^{3)}$ used in a concentration of $32 \mu \mathrm{g} \mathrm{mL}{ }^{-1}$ 
485 Table 2. Results from permutation-based Analysis of Variance tests for differences among 486 groups of samples, using Type III sums of squares based on 999 permutations of residuals 487 under a reduced model. The factors are antibiotic and Ag-NPs. (SS = square sum, MS = 488 medium square, $\mathrm{F}=$ ratio of $\mathrm{SS} / \mathrm{MS}$ )

$\begin{array}{lrrrrc}\text { Source } & \text { df } & \text { SS } & \text { MS } & \text { F } & \text { p } \\ \text { Antibiotic } & 7 & 91580 & 13083 & 15.9 & 0.001 \\ \text { Ag-NPs } & 2 & 2962 & 1481 & 1.8 & 0.164 \\ \text { Antibiotic XAg-NPs } & 14 & 13591 & 971 & 1.2 & 0.264 \\ \text { Residual } & 48 & 39565 & 824 & & \\ \text { Total } & 71 & 147700 & & & \end{array}$

491 Table 3. Results of pairwise tests for differences in counts between antibiotic treatments 492 from permutation-based Analysis of Variance tests using Type III sums of squares based on 493999 permutations of residuals under a reduced model. Values of $\mathrm{t}$ and its significance is 494 indicated by: $\mathrm{n}: \mathrm{p}>0.05 ; \quad *: 0.05 \geq \mathrm{p}>0.01 ; \quad * *: 0.01 \geq \mathrm{p}>0.001, \quad * * *: \mathrm{p} \leq 0.001$.

\begin{tabular}{|c|c|c|c|c|c|c|c|c|}
\hline & $\begin{array}{l}\text { Cyclo- } \\
\text { heximide }\end{array}$ & $\begin{array}{l}\text { Erythro- } \\
\text { mycin }\end{array}$ & $\begin{array}{l}\text { Oxytetra- } \\
\text { cycline }\end{array}$ & $\begin{array}{l}\text { Sulfa- } \\
\text { diazine }\end{array}$ & $\begin{array}{l}\text { Trimetho- } \\
\text { prim }\end{array}$ & $\begin{array}{l}\text { Linco- } \\
\text { mycin }\end{array}$ & $\begin{array}{l}\text { Cefta- } \\
\text { zidime }\end{array}$ & $\begin{array}{l}\text { Amoxy- } \\
\text { cillin }\end{array}$ \\
\hline rythromycin & $6.91 * * *$ & & & & & & & \\
\hline Oxytetracycline & $6.61 * * *$ & $4.90 * *$ & & & & & & \\
\hline Sulfadiazine & $5.44 * * *$ & $6.49^{* * *}$ & $4.90 * *$ & & & & & \\
\hline Trimethoprim & $4.34 * * *$ & $4.91 * * *$ & $4.22 * *$ & $1.68 \mathrm{n}$ & & & & \\
\hline Lincomycin & $4.74 * * *$ & $5.76^{* *}$ & $4.82 * * *$ & $1.45 n$ & $0.46 n$ & & & \\
\hline Ceftazidime & $6.38 * * *$ & $5.64 * *$ & $2.00 \mathrm{n}$ & $3.74 * *$ & $3.69 * *$ & $4.10^{* *}$ & & \\
\hline Amoxycillin & $6.57 * * *$ & $3.10 *$ & $0.11 \mathrm{n}$ & $4.56^{* *}$ & $4.13^{* *}$ & $4.66^{* *}$ & $1.52 \mathrm{n}$ & \\
\hline Vancomycin & $3.26^{* * *}$ & $2.33^{*}$ & $2.03^{*}$ & $0.95 n$ & $0.13 n$ & $0.38 n$ & $1.81 \mathrm{n}$ & $2.02 *$ \\
\hline
\end{tabular}

